\title{
DE VERWACHT WORDENDE GROOTE GEBEURTENIS ONDER DE BRITSCH-INDIERS IN SURINAME
}

DOOR

\author{
H. N. HAJARY
}

Toen in 1916 het transport van ongeveer 300 Britsch-Indische contractkoelies in Suriname aankwam, leefden wij in de hoop, dat daarop nog meer aanvoeren volgen zouden, vóór de verstrijking van den termijn van drie jaaren (tot 1919), binnen welken immigreerende koloniën nog de gelegenheid hadden Britsch-Indiërs aan te werven.

Deze hoop werd evenwel niet vervuld, terwijl de pogingen aangewend tot vrije immigratie geen resultaten opleverden.

Door deze haast plotselinge stopzetting der contract-immigratie zag de Britsch-Indische bevolking in Suriname zich voor een groot en moeilijk probleem geplaatst.

Bij haar rees namelijk de vraag, of door die stopzetting de in Suriname gevestigden, in het bijzonder de hiergeborenen, hun taal, zeden en gewoonten niet zouden prijsgeven.

De regelmatige vroegere nieuwe aanvoeren toch waren prikkels geweest om de aloude Indische tradities getrouw na te leven.

Bij een nieuwe aanvoer trokken vele contractanten en oudcontractanten naar het koelie-depôt, niet alleen uit belangstelling om de nieuwkomers te begroeten, doch ook in de hoop onder hen familieleden, dorps- of stadsgenooten aan te treffen.

En keerden zij naar huis terug, dan hadden allen dezelfde gedachte: „onze band met het stamland is weder versterkt”.

Hebben zij, trots het gemis van versch bloed, hun taal, zeden en gewoonten in al de reeds verloopen jaren kunnen handhaven? Deze vraag kan met een volmondig ,ja” worden beantwoord.

Reeds vier jaren na den laatsten aanvoer, en wel in 1920, konden wij in het verslag van de Surinaamsche Immigranten Vereeniging o.m. de volgende passage lezen: „Op het behoud van hunne zeden en gewoonten zijn de Hindostani's bijzonder gesteld, eveneens op het behoud van hun taal, al geven zij toe, dat zij 


\begin{tabular}{|c|c|c|c|c|c|c|c|c|c|c|c|c|c|c|c|c|}
\hline \multirow[b]{2}{*}{$\begin{array}{l}5 \text { jarige } \\
\text { periode }\end{array}$} & \multirow[b]{2}{*}{ Groepen } & \multirow{2}{*}{$\begin{array}{l}\text { Gemid- } \\
\text { delde be- } \\
\text { volking } \\
\text { van de } \\
\text { groep }\end{array}$} & \multirow{2}{*}{$\mid \begin{array}{c}\text { Gemiddelde } \\
\text { bevolking } \\
\text { van Suri- } \\
\text { name, uit- } \\
\text { gezonderd } \\
\text { Boschnegers } \\
\text { en Indianen }\end{array}$} & \multicolumn{12}{|c|}{ waarvan in: } & \multirow{2}{*}{ 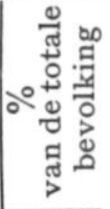 } \\
\hline & & & & $\begin{array}{c}\text { Para- } \\
\text { maribo }\end{array}$ & $\%$ & $\begin{array}{c}\text { Comme } \\
\text { wijne }\end{array}$ & $\%$ & $\begin{array}{l}\text { Coronie } \\
\text { en } \\
\text { Maro- } \\
\text { wijne }\end{array}$ & $\%$ & 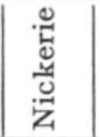 & $\%$ & $\begin{array}{l}\text { Sara- } \\
\text { macca }\end{array}$ & $\%$ & $\begin{array}{c}\text { Suri- } \\
\text { name }\end{array}$ & $\%$ & \\
\hline \multirow[t]{6}{*}{$1925 / 1929$} & Inlanders & 58.400 & - & 37.100 & 63.53 & 3.900 & 6.68 & 4.100 & 7.02 & 4.500 & 7.70 & 1.500 & 2.57 & 7.300 & 12.50 & - \\
\hline & Br. Indiërs & 33.800 & - & 3.900 & 11.54 & 4.900 & 14.50 & 100 & 0.29 & 4.400 & 13.02 & 3.200 & 9.47 & 17.300 & 51.18 & - \\
\hline & Ned. Indiërs & 27.000 & - & 700 & 2.59 & 15.300 & 56.67 & 200 & 0.74 & 3.700 & 13.70 & 1.200 & 4.45 & 5.900 & 21.85 & - \\
\hline & Inlanders & - & & - & 29.45 & - & 3.09 & - & 3.25 & - & 3.57 & - & 1.19 & - & 5.80 & 46.35 \\
\hline & Br. Indiërs & - & 126.000 & - & 3.09 & - & 3.89 & 一 & 0.08 & - & 3.49 & - & 2.54 & - & 13.73 & 26.82 \\
\hline & Ned. Indiërs & - & & - & 0.56 & - & 12.14 & - & 0.16 & - & 2.94 & - & 0.95 & 一 & 4.68 & 21.43 \\
\hline \multirow[t]{6}{*}{$1930 / 1934$} & Inlanders & 61.700 & - & 39.200 & 63.53 & 3.500 & 5.66 & 4.500 & 7.30 & 4.700 & 7.62 & 1.700 & 2.76 & 8.100 & 13.13 & - \\
\hline & Br. Indiërs & 37.500 & - & 4.400 & 11.73 & 4.900 & 13.07 & 100 & 0.27 & 4.900 & 13.07 & 3.500 & 9.33 & 19700. & 52.53 & 一 \\
\hline & Ned. Indiërs & 32.200 & - & 900 & 2.79 & 18.100 & 56.21 & 200 & 0.62 & 4.000 & 12.42 & 1.500 & 4.66 & 7.500 & 23.30 & - \\
\hline & Inlanders & - & & - & 28.22 & - & 2.52 & 一 & 3.24 & - & 3.38 & - & 1.23 & - & 5.83 & 44.42 \\
\hline & Br. Indiërs & - & 138.900 & - & 3.17 & - & 3.53 & 一 & 0.07 & - & 3.53 & - & 2.52 & - & 14.18 & 27.- \\
\hline & Ned. Indiërs & - & & - & 0.65 & - & 13.03 & - & 0.14 & - & 2.88 & -1 & 1.08 & - & 5.40 & 23.18 \\
\hline
\end{tabular}


daarnevens de taal van het land, dat zij tot nieuw vaderland hebben gekozen, behooren te kunnen spreken."

Geen ijdele klanken, doch woorden, die heden ten dage nog dezelfde kracht hebben behouden en die in daden zijn omgezet.

Te meer klemt dit als men nagaat dat het aantal op 31 December 1934 in Suriname woonachtige Britsch-Indiërs 39.000 bedroeg, waarvan 29.800 het Hindoëisme en \pm 7.000 den Mahomedaanschen godsdienst beleden, dus waarvan nog geen 3.000 of $7 \%$ tot andersdenkenden moesten worden gerekend.

Van deze $3.000 \mathrm{zal}$ er wel een belangrijk deel de adats hunner voorouders willen naleven, doch dit nalaten uit hoofde van hun onbekendheid daarmede.

Is de Britsch-Indiër trotsch op de wetenschap, dat hij uit eigen natuurlijken drang zich vastgehouden heeft aan zijn taal, zeden en gewoonten, trotscher is hij, nu door Zijne Excellentie den Gouverneur twee ontwerp-verordeningen zijn ingediend aan de Koloniale Staten betreffende het wettig verklaren van naar Oostersche begrippen gesloten huwelijken.

Hij, de Britsch-Indiër, ziet daarin een erkenning door het Surinaamsche Gouvernement van datgene, waaraan hij zich in den loop der jaren zoo krampachtig heeft vastgehouden: „zijn adat".

Van Prof. Dr. J. C. Kielstra, onder wiens bestuur wij de inwerkingtreding dier verordeningen ook gaarne zouden zien, zal het Surinaamsch-Hindostansch nageslacht met dankbaarheid getuigen, dat hij den eersten steen gelegd heeft tot verderen opbouw onder Nederlandsch Gezag en op Zuid-Amerikaanschen bodem, van een stukje Hindoe- en Mahomedaansche cultuur.

$\mathrm{Nu}$ er zulke belangrijke wijzigingen te verwachten zijn in de rechtspositie der Aziaten, wil ik den lezers aantoonen, welke plaats de Britsch-Indische bevolkingsgroep in Suriname inneemt.

De gegevens, loopende over 2-vijfjarige perioden, n.l. 1925/1929 en 1930/1934, zijn ontleend aan de verslagen van Bestuur en Staat, welke jaarlijks worden uitgegeven.

Ten slotte volgt hieronder een grafiek over een periode van 10 jaren (1925/1934) van de verschillende bevolkingsgroepen in Suriname. 


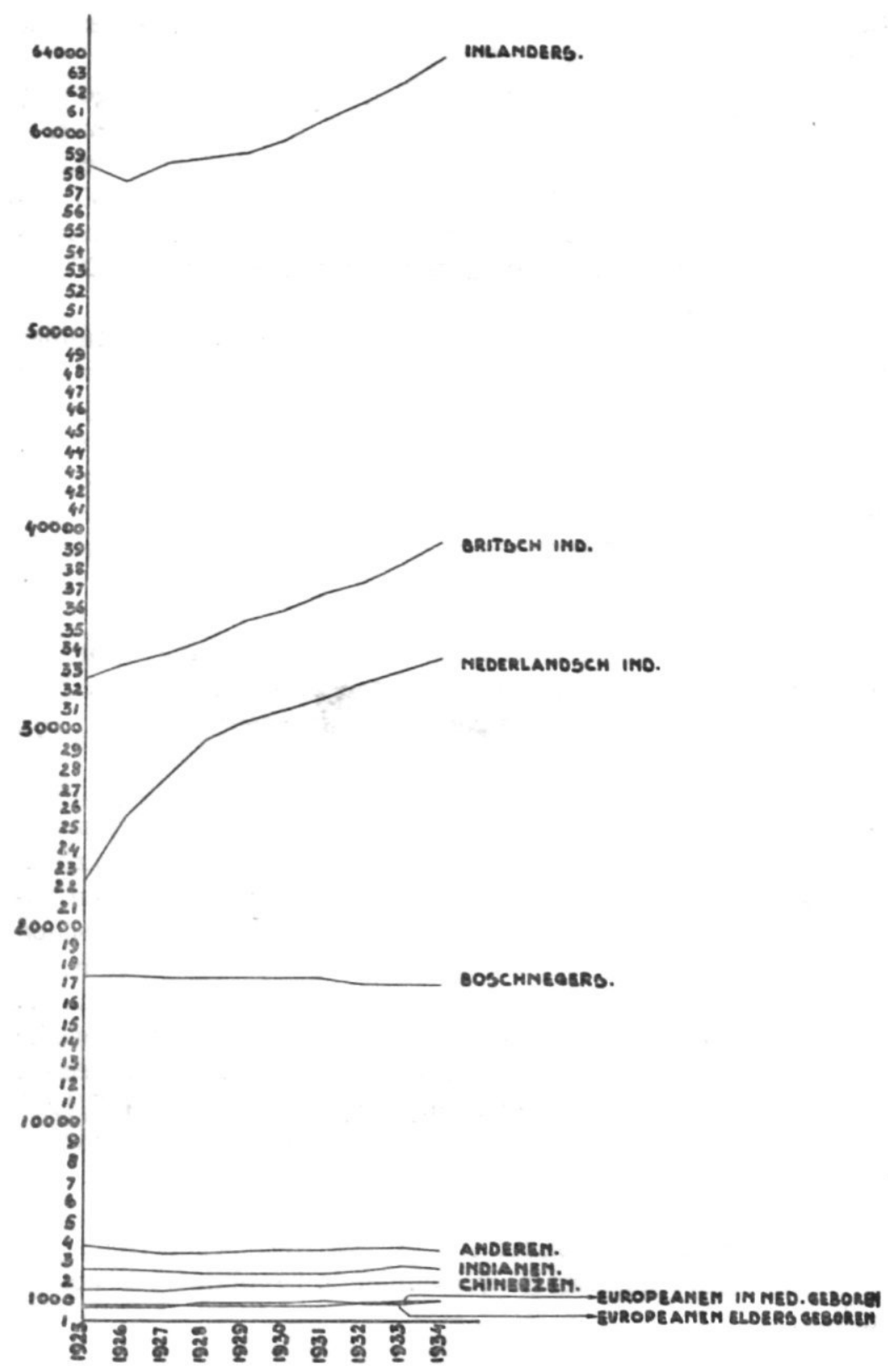

